Volume 12

Issue 2 Images And Collective Violence:

Function, Use And Memory

Article 5

$10-2018$

\title{
Nineteen Minutes of Horror: Insights from the Scorpions Execution Video
}

Iva Vukušić

Utrecht University

Follow this and additional works at: https://digitalcommons.usf.edu/gsp

\section{Recommended Citation}

Vukušić, Iva (2018) "Nineteen Minutes of Horror: Insights from the Scorpions Execution Video," Genocide Studies and Prevention: An International Journal: Vol. 12: Iss. 2: 35-53.

DOI:

https://doi.org/10.5038/1911-9933.12.2.1527

Available at: https://digitalcommons.usf.edu/gsp/vol12/iss2/5

This Articles is brought to you for free and open access by the Open Access Journals at Digital Commons @ University of South Florida. It has been accepted for inclusion in Genocide Studies and Prevention: An International Journal by an authorized editor of Digital Commons @ University of South Florida. For more information, please contact digitalcommons@usf.edu. 


\section{Nineteen Minutes of Horror: Insights from the Scorpions Execution Video}

\section{Acknowledgements}

I wish to thank the Archives and Records Section of the Mechanism for International Criminal Tribunals and my colleagues Vladimir Petrović and Jelena Stevančević on the assistance they provided as I worked on this article. 
Nineteen Minutes of Horror: Insights from the Scorpions Execution Video

\author{
Iva Vukušić \\ Utrecht University \\ Utrecht, The Netherlands
}

\begin{abstract}
Introduction
The so-called Scorpions video is one of the most disturbing audiovisual traces of the wars in the former Yugoslavia in the 1990s. It shows one of the many mass executions that followed the fall of the United Nations' protected area around the town of Srebrenica in eastern Bosnia, in mid-July 1995. The crime itself was a culmination of the brutal war that was ripping Bosnia and Herzegovina apart from the spring of 1992. The video, described as shocking after it emerged, shows men in dark uniforms, some wearing red berets, executing six men, three of whom were underage, in a deserted hamlet in the hills of Bosnia. ${ }^{1}$ That video is a key piece of evidence used to prosecute perpetrators for the executions committed in the aftermath of the Bosnian Serb Army entering the town, led by its charismatic, yet brutish commander, Ratko Mladić. ${ }^{2}$ Mladić, his subordinates, and civilian counterparts like Radovan Karadžić have been tried and convicted at the International Criminal Tribunal for the former Yugoslavia (ICTY) in The Hague, and this video is part of the trial record in many of those cases. ${ }^{3}$

The video was first shown during the trial of the Serbian president Slobodan Milošević, in June 2005, and it immediately caused a storm, both in international and Serbian media outlets. ${ }^{4}$ Milošević died before judgment, less than a year later, and the storm was short-lived, especially in Serbian society. ${ }^{5}$ If it can be said that it led to a sort of reckoning, it was a brief one. ${ }^{6}$ However, perpetrators have been convicted, some for committing genocide, due also to this crucial piece of evidence. Apart from that judicial value, the video tells us a lot about the nature of the crime itself, and the attitudes perpetrators held towards their victims. That is why this article aims to revisit those crucial nineteen minutes of video footage, and dissect it; with a purpose of understanding what it tells us about the executions following the capture of Srebrenica, but also about the prosecution of international crimes. ${ }^{7}$ In this article, the focus is on those who actually participated in the killings, in the precise moments when the massacre was committed, and not those who sent them to fulfill this task. Sources from the proceedings against those pulling the trigger will be drawn on most. In sum, the primary questions concern the characteristics of the act of execution, and those who commit it, as well as the importance of this particular video as evidence in court.
\end{abstract}

The Crime After The Fall of Srebrenica

All my close relatives, my entire family, was under the ground.

I had no hope whatsoever.

There was no one I could wait for.

${ }^{1}$ Melissa Block, “Execution Video Shocks Serbia," NPR, June 3, 2005, accessed July 18, 2017. http://www.npr.org/ templates/story/story.php?storyId=4679742.

2 Prosecutor v. Mladic, Fourth Amended Indictment, December 16, 2011, IT-09-92-PT, accessed July 25, 2017, http://www. icty.org/x/cases/mladic/ind/en/111216.pdf .

${ }^{3}$ Srebrenica-related ICTY cases are against accused: Dražen Erdemović, Slobodan Milošević, Vidoje Blagojević and Dragan Jokić, Radislav Krstić, Radovan Karadžić, Ratko Mladić, Momir Nikolić, Dragan Obrenović, Momčilo Perišić, Popović et al., Jovica Stanišić and Franko Simatović, and Zdravko Tolimir. More information available at the ICTY website, accessed July 22, 2017, http://www.icty.org/en/action/cases/4.

${ }^{4}$ Prosecutor v. Slobodan Milosevic, Initial Indictment Kosovo, May 22, 1999, IT-99-37, accessed July 25, 2017, http://www.icty. org/x/cases/slobodan milosevic/ind/en/mil-ii990524e.htm.

${ }^{5}$ Eric Gordy, Guilt, Responsibility and Denial: The Past at Stake in Post-Milosevic Serbia (Philadelphia: University of Pennsylvania Press, 2013), 124.

${ }^{6}$ Vladimir Petrović, "A Crack in the Wall of Denial: The Scorpions Video in and out of the Courtroom," in Narratives of Justice In and Out of the Courtroom: Former Yugoslavia and Beyond, ed. Dubravka Žarkov and Marlies Glasius (New York: Springer, 2014), 103.

${ }^{7}$ The precise nineteen minutes can be accessed here, along with other, related evidence material: $\underline{\text { http://srebrenica.sense- }}$ agency.com/en/. The transcript of the video is available in English.

Iva Vukušić. "'Nineteen Minutes of Horror: Insights from the Scorpions Execution Video" 12, 2 (2018): 35-53. @2018 Genocide Studies and Prevention.

https://doi.org/10.5038/1911-9933.12.2.1527 
The truth had come out,

And it became apparent that I'm really alone.

Mirsada Malagić, witness at the ICTY trial of Ratko Mladić, May 16, $2013^{8}$

Before this video was shown in court, much was already known about what happened in those days following the fall of Srebrenica. ${ }^{9}$ That is largely due to the work of the investigative team at the Prosecutor's Office at the ICTY, and in particular its lead investigator on the case, Jean-Rene Ruez. ${ }^{10}$ He led his team, for years, tirelessly, in putting together this puzzle. Ruez was already in Bosnia in the weeks following the Bosnian Serb takeover of the territory, as it was becoming increasingly clear that thousands of men were unaccounted for. ${ }^{11}$ His team of investigators, along with analysts, and prosecutors at the ICTY managed to reconstruct the sequence of events up to knowing what important actors were doing, hour per hour. Before the video was released, several people pleaded guilty at the ICTY for crimes related to Srebrenica, and gave statements about the event and their participation in it. ${ }^{12}$ Early on, it was Dražen Erdemović, member of the Tenth Sabotage Detachment of the Bosnian Serb Army, who came forward in 1996, and shed much-needed light as to what happened at execution sites such as Branjevo farm, and in Pilica, in eastern Bosnia. ${ }^{13}$

It was known, in 2005, that thousands were executed in areas across northeastern Bosnia in the week following the fall of Srebrenica, many of them around Zvornik. The victims were not only pre-war Srebrenica area residents, but also refugees from eastern Bosnia towns that fled to Srebrenica, to escape from the violent campaigns to expel them, that began in 1992. In July 1995, victims were hunted down, captured, and executed, sometimes weeks after the town fell. It was known that victims were killed in large numbers after being bussed to, at times, remote locations, and then buried at or close to the scene of the crime, often by civilians drafted through Bosnian Serb local authorities, manning heavy machinery. This was known because several men testified in court about getting rid of those bodies. ${ }^{14}$ The few survivors came forward and spoke in court in The Hague, sometimes with their identities concealed, about what they lived through. ${ }^{15}$ Researchers, journalists, and activists collected information, and published it. ${ }^{16}$

Testimonies emerged that corroborated those horrific accounts and added stories of incredible suffering, almost too difficult to put into words. ${ }^{17}$ Those left behind spoke about the effects the crime had on their lives, recounting how much they missed their children, ${ }^{18}$ and how not knowing

\footnotetext{
${ }^{8}$ Prosecutor $v$. Ratko Mladic, testimony of witness Mirsada Malagić, May 16, 2013, IT-09-92. Transcript page 11218, lines 2123, accessed July 20, 2017, http://www.icty.org/x/cases/mladic/trans/en/130516IT.htm.

9 Prosecutor v. Slobodan Milosevic, testimony of witness Obrad Stevanović, June 1, 2005, IT-02-54, accessed July 30, 2017, http://www.icty.org/x/cases/slobodan milosevic/trans/en/050601IT.htm.

${ }^{10}$ Sonja Biserko, “Intervju sa Žan-Rene Ruezom: Srebrenica je više od tragedije," in Srebrenica: Od poricanja do priznanja, ed. Sonja Biserko (Helsinški odbor za ljudska prava u Srbiji, 2005), 738.

${ }^{11}$ United Nations Security Council, Press Release SC/6122/Rev. 1 3591 st Meeting (Night), November 9, 1995, accessed July 10, 2017, http://www.un.org/press/en/1995/19951109.sc6122.r1.html.

${ }^{12}$ See ICTY cases against Momir Nikolic (IT-02-60/1), Dragan Obrenovic (IT-01-43), accessed July 30 2017, http://www.icty. org/en/action/cases/4.

${ }^{13}$ Prosecutor v. Drazen Erdemovic, IT-96-22, accessed July 30 2017, http://www.icty.org/cases/party/683/4.

${ }^{14}$ Prosecutor v. Blagojevic and Jokic, testimony of witness Krsto Simić, February 23, and 24, 2004, IT-02-60, accessed July 20 2017, http://www.icty.org/x/cases/blagojevic jokic/trans/en/040223IT.htm, http://www.icty.org/x/cases/blagojevic jokic/trans/en/040224ED.htm.

${ }^{15}$ Testimonies of several survivors are available here, accessed July 20, 2017, http://srebrenica.sense-agency.com/en/.

${ }^{16}$ The report on Srebrenica was published by NIOD, the Dutch Institute for War, Holocaust and Genocide Studies in Amsterdam, accessed July 20, 2017, http://www.niod.nl/en/srebrenica-report/report.

${ }^{17}$ Prosecutor v. Vujadin Popovic et al., testimony of witness PW-101, February 22, 2007, IT-05-88. Transcript pages 75817582, accessed July 28, 2017, http://www.icty.org/x/cases/popovic/trans/en/070222ED.htm; Prosecutor v. Ratko Mladic, testimony of witness RM-313, June 6, 2014, IT-09-92, accessed July 30, 2017, http://www.icty.org/x/cases/mladic/trans/ en/130606ED.htm.

${ }^{18}$ Prosecutor v. Radislav Krstic, IT-98-33, testimony of witness DD, and other testimonies of survivors are available here, accessed July 28, 2017, http://srebrenica.sense-agency.com/en/.
} 
where they ended up haunted them. ${ }^{19}$ Experts in archeology, pathology, and anthropology spoke in court about the efforts the Bosnian Serb Army put in place about two, three months after, to hide the crime. ${ }^{20}$ Their re-digging of large primary mass graves included taking out the bodies that had been decomposing already, again with heavy machinery, and transporting them to remote locations. ${ }^{21}$ This process led to the bodies being ripped apart, which made the subsequent process of their identification, and return to families for a proper burial, that much harder. There were instances in which one person's remains were found in three, or even four different mass gravessometimes with some bones still missing. ${ }^{22}$ Nevertheless, the International Commission on Missing Persons (ICMP) has managed to recover, and identify, the remains of more than 6,930 people, and, by July 2015, 6,241 have been buried in the Memorial in Potočari, just across the road from the UN base where many sought refuge. ${ }^{23}$

In 2005, all of that was known to those who cared about knowing it. However, what the Scorpions video showed was, for the first time, and in only a few minutes of footage, what it was like for those men who were captured, and then executed. It showed how they were treated, without mercy, and the condition that they were in. Their experience, captured on camera, made it possible for those watching to imagine what those thousands of people went through, in a way that was previously impossible. The video provided the opportunity to hear, from the mouths of the perpetrators, how they spoke to the victims. It was no one else, and it was not a recollection after the fact. It was the perpetrators themselves speaking. The overwhelming amount of evidence collected and verified in court, of which this video is a crucial part, led to the ICTY and the International Court of Justice, ${ }^{24}$ describing the executions after the fall of the enclave as a genocide. It is important to remember, all genocide convictions at the ICTY were related to mass executions after the fall of Srebrenica. ${ }^{25}$

\section{Theoretical Framework, Approach and Method}

Images of mass atrocity have been the subject of study and debate ever since the development of technology allowed cameras to be carried around to document events. The Second World War, the horror of the Holocaust and the trials that followed in Nuremberg and elsewhere, made images of crime available - to judges, but also historians, and the wider public. Much about images has been discussed, and a central point has been the value of images depicting violence for history, as well as their probative value. Audiovisual material was crucial to how we think of, and remember, the Holocaust. ${ }^{26}$ In court, the first use of film as evidence of mass atrocity was at the International Military Tribunal in Nuremberg in 1945. ${ }^{27}$ Among those films, "Nazi Concentration Camps" is

${ }^{19}$ Expert testimony of witness Teufika Ibrahimefendić is available here, accessed July 28, 2017, http://srebrenica.senseagency.com/en/.

${ }^{20}$ Expert testimony of several anthropologists, archeologists and pathologists is available here, accessed July 28, 2017, http://srebrenica.sense-agency.com/en/.

${ }^{21}$ The distinction between primary and secondary graves are explained well in the expert witness testimony clips available here, accessed July 28, 2017, http://srebrenica.sense-agency.com/en/.

${ }_{22}$ Prosecutor v. Radovan Karadzic, testimony of witness Amor Mašović, April 10, 2012, IT-95-5/18. Transcript page 27300, lines 12-20, accessed July 27, 2017, http://www.icty.org/x/cases/karadzic/trans/en/120410ED.htm. Mašović is the Chairman of the Bosnian Federal Commission for Missing Persons. He has been involved in finding missing persons and the recovery of remains since the time of the war.

${ }^{23}$ International Commission on Missing Persons, "Srebrenica Figures as of 02 July 2015," Press Release, accessed September 11, 2018, https://www.icmp.int/news/infographic-provides-latest-facts-and-figures-on-srebrenicagenocide/.

${ }^{24}$ International Court of Justice, Case Concerning the Application of the Convention on the Prevention and Punishment of the Crime of Genocide, February 26, 2007, accessed July 12, 2017, http://www.icj-cij.org/files/case-related/91/09120070226-JUD-01-00-EN.pdf. More information about this case, Bosnia and Herzegovina v. Serbia and Montenegro can be accessed here: http://www.icj-cij.org/en/case/91/judgments.

${ }^{25}$ More information about ICTY Srebrenica cases available here, accessed December 14, 2017, http://www.icty.org/ specials/srebrenica20/?q=srebrenica20/.

${ }^{26}$ James Gow and Cathie Carmichael, ed., History: The Journal of the Historical Association, Vol. 98, Issue 4, No. 332 (2013).

${ }^{27}$ Helen Lennon, "A Witness to Atrocity: Film as Evidence in International War Crimes," in Holocaust and the Moving Image: Representations in Film and Television since 1933, ed. Toby Haggith and Joanna Newman (London: Thomson Press, 2005), 67. 
likely the most well-known, and contains images that have forever shaped public perceptions of the Holocaust, and in particular, the camps. Such films, containing images of atrocity, represent some of the most powerful obstacles to denial available. In the context of ICTY trials, there were at least six hundred video exhibits in the unfinished trial of Slobodan Milošević. ${ }^{28}$ In that case, as in others, the question of authenticity of footage was a key point of contention. ${ }^{29}$

As Helen Lennon demonstrates, images can be immediate, spontaneous, and chillingly succinct. They can be circulated rapidly, viewed by many individuals at once, and permanently archived in collective memory. ${ }^{30}$ What the Scorpions video depicts, similar to images from Nazi camps, is the labor that was necessary to exterminate people, and the matter-of-factness with which this was done. It is precisely that, writes Judith Keilbach, which causes a shock. ${ }^{31}$ It is the ease that comes with this labor, so painfully obvious in the Scorpions footage that is perplexing.

The Scorpions video, and evidence like it, stands alongside some of the previous examples of visually documenting atrocity crimes, as they are committed. That is why records i.e. evidence material such as documents, testimony and other moving or still images, are important for creating a narrative about past events - both in and out of the courtroom. All of that evidence works in concert to tell a story. Wilson wrote about history in international criminal trials, ${ }^{32}$ and others studied the use of historical forensic evidence in $\operatorname{court}^{33}$, and the potential of the ICTY archive specifically, as a rich resource for researchers interested in the former Yugoslavia. ${ }^{34}$ There is thus substantial agreement about evidence presented in trial having an important role in historical research.

Audiovisual records and images of executions from the wars that engulfed the former Yugoslavia in the 1990s, are rare..$^{35}$ One other example comes from the ICTY trial of Goran Jelisić, for crimes in Brčko, early on in the conflict, in $1992 .{ }^{36}$ In that trial, still images of Jelisić executing unarmed men have been included in the trial record. ${ }^{37}$ Videos recorded by perpetrators themselves-during the act of killing - where what they say is audible, are even harder to find. The Scorpions video is thus a unique opportunity to come closer to the act, in order to scrutinize it. While doing that, the men whose lives were so brutally cut short are nevertheless not removed from the analysis. From here, the article proceeds in three sections. The first discusses the unit whose members committed the murders in the video in question. The second analyzes the nineteen minutes of video in detail, taking apart some of the spoken, and unspoken, elements of it. Finally, the third section looks at the judicial and social aftermath of the release of the video, primarily within Serbian society.

This article is the result of a critical assessment of primary sources from trials, and attentive viewing of the video, that enabled a scrutiny of the spoken and the unspoken in it. Conclusions are based on juxtaposing the video with elements of various trial records, and interpreting them

\footnotetext{
${ }^{28}$ Lennon, A Witness to Atrocity, 69.

${ }^{29}$ Ibid.; More on the Milošević trial, see: Gideon Boas, The Milosevic Trial: Lessons for the Conduct of Complex International Criminal Proceedings (Cambridge, UK: Cambridge University Press, 2007); Timothy Waters, ed., The Milosevic Trial, An Autopsy (Oxford: Oxford University Press, 2014); Judith Armatta, Twilight of Impunity: The War Crimes Trial of Slobodan Milosevic (Durham: Duke University Press, 2010); Nevenka Tromp, Prosecuting Slobodan Milosevic: The Unfinished Trial (Routledge, 2016).

${ }^{30}$ Lennon, A Witness to Atrocity, 66

${ }^{31}$ Judith Keilbach, "Photographs, Symbolic Images, and the Holocaust: On the (Im)possibility of Depicting Historical Truth," History and Theory, Theme Issue 47 (2009), 54-76.

${ }^{32}$ Richard Ashby Wilson, Writing History in International Criminal Trials (New York: Cambridge University Press, 2011).

${ }^{33}$ Vladimir Petrović, The Emergence of Historical Forensic Expertise: Clio Takes the Stand (New York: Routledge, 2017).

${ }^{34}$ Iva Vukušić, "The Archives of the International Criminal Tribunal for the former Yugoslavia," History: The Journal of the Historical Association, Vol. 98, Issue 4, No. 332 (2013).

${ }^{35}$ It is entirely possible that more recordings and images exists, but they have not surfaced yet, and have not been used in court.

${ }^{36}$ Prosecutor v. Goran Jelisic, Trial Judgment, December 14, 1999, IT-95-10, accessed on July 30, 2017 http://www.icty.org/x/ cases/jelisic/tjug/en/jel-tj991214e.pdf. More about Goran Jelisić can be found in the book by Slavenka Drakulić, They Would Never Hurt a Fly: War Criminals on Trial in The Hague (London: Penguin Books, 2004), 66.

${ }^{37}$ Prosecutor v. Goran Jelisic, Image, Exhibit P3, December 1, 1998, IT-95-10, accessed on July 20, 2017, http://icr.icty.org/ LegalRef/CMSDocStore/Public/English/Exhibit/Indexable/IT-95-10/ACE2782R0000021509.jpg.
} 
together. The exploration thus includes words spoken by the same individuals in the video, and later, at their trial in Belgrade in 2005, and 2006. The article further draws on the records of other proceedings relating to Srebrenica, primarily those of Popović et al., Zdravko Tolimir, Ratko Mladić and Radovan Karadžić.

\section{The Scorpions Unit}

The Scorpions are one of the most long-lasting units in the entire Yugoslav conflict between 1991, when violence erupted in Croatia, until 1999, when it ravaged Kosovo. In that period, it changed shapes and affiliations, at least on paper, but its core remained largely the same. ${ }^{38}$ It was a paramilitary unit, operated covertly, like other units such as Željko Ražnatović Arkan's Serbian Volunteer Guard, under the umbrella of the Serbian Ministry of Internal Affairs, and specifically, its State Security Service. ${ }^{39}$ The unit was named after a type of weapon originally developed in Czechoslovakia and later produced in Yugoslavia. The unit first became active in Croatia, being tasked with securing the newly conquered oil fields in Slavonija, a rich region in the east, close to the border with Serbia. Their base was in Đeletovci, a small town on the eastern edge of Croatia, then held by a mix of forces including the Yugoslav People's Army, local Serbs and units from Serbia proper. The Scorpions' war path is marked in particular by the executions some of the members committed in the hamlet of Godinjske bare near Trnovo, Bosnia, in 1995, and the murders they carried out in the small town of Podujevo, Kosovo, four years later. ${ }^{40}$ What is particularly interesting about this unit is that the members often originated from the same town, and were relatives, friends and acquaintances long before the war. That, according to one member, brought a special sense of closeness to the unit. ${ }^{41}$

The Scorpions were established early on in the war, as local Serbs rebelled against Croatian independence, and formed the para-state called Republika Srpska Krajina ${ }^{42}$ The initial guarding of the oil fields was part of resource exploitation that funded the war effort, and made some of those involved rich. ${ }^{43}$ They fought alongside the army of the Republika Srpska Krajina, within which they were incorporated, and later with the Bosnian Serb Army. Finally, after the wars in Bosnia and Croatia, the Scorpions became the reserve of the Special Anti-terrorist unit of the Serbian Ministry of Internal Affairs. ${ }^{44}$ Apart from oil, they were involved in widespread harvesting of local highquality oak that they transported out of the territory, and sold. ${ }^{45}$ There are instances of the Serbian State Security providing them with IDs, and a salary. ${ }^{46}$ According to some of the members, the

${ }^{38}$ Dejan Anastasijević, “Kratka istorija paravojnih jedinica u jugoslavenskim ratovima 1991-1995 - Grabljive zveri i otrovne bube," YU Historija, n.d., accessed on July 25, 2017, http://www.yuhistorija.com/serbian/ratovi 9199 txt01c. html; Miloš Vasić and Filip Švarm, "Paramilitary Formations in Serbia: 1990-2000," in In the Triangle of State Power: Army, Police, Paramilitary Units, ed. Stipe Sikavica (Belgrade: Helsinki Committee for Human Rights in Serbia, 2001).

${ }^{39}$ Anastasijević, Kratka istorija paravojnih jedinica u jugoslavenskim ratovima, James Gow, The Serbian Project and its Adversaries: A Strategy of War Crimes (London: Hurst \& Company, 2003).

${ }^{40}$ Saša Cvjetan has been tried for the crime in Podujevo, where fourteen Albanians were killed, and at least five children wounded in March 1999. Cvjetan was convicted in Belgrade in 2005, just days after the Scorpions video was released in The Hague. Tanja Tagirov, “Škorpion pred sudom,” Vreme, June 16, 2005, accessed July 20, 2017, http://www.vreme. com/cms/view.php?id=419054.

${ }^{41}$ Lazar Stojanović, Škorpioni Spomenar, film (2007; Belgrade: Humanitarian Law Center), min 28, https://www.youtube. com/watch?v=nqsDRw04Z6U; Fond za humanitarno pravo, Škorpioni od zločina do pravde, 2008, accessed July 24, 2017, http://www.hlc-rdc.org/wp-content/uploads/2012/06/Skorpioni.pdf.

${ }^{42}$ Anastasijević, Kratka istorija paravojnih jedinica u jugoslavenskim ratovima; Miloš Vasić and Filip Švarm, "Paramilitary Formations in Serbia: 1990-2000," in In the Triangle of State Power: Army, Police, Paramilitary Units, ed. Stipe Sikavica (Belgrade: Helsinki Committee for Human Rights in Serbia, 2001).

${ }^{43}$ Miloš Vasić, “Poreklo moći i bogatstva," Vreme, June 16, 2005, accessed July 30, 2017, http://www.vreme.com/cms/view. php?id=419055.

${ }^{44}$ Helsinški odbor, Slučaj Škorpioni, Peščanik, September 14, 2008, accessed July 20, 2017, http://pescanik.net/slucajskorpioni/.

${ }^{45}$ Helsinški odbor, Slučaj Škorpioni.

${ }^{46}$ Dejan Anastasijević, “Ubod Škorpiona,” Vreme, December 25, 2003, accessed July 21, 2017, http://www.vreme.com/cms/ view.php?id=361981. 
pay in the unit was better than that in other units active at the time. ${ }^{47}$ The unit's insignia evolved with time, including an image of a scorpion superimposed on a black background, and the Serbian three-colored flag. When deployed in Bosnia, the members were advised to remove their insignia, so in case of capture, they could deny which unit they belonged to. ${ }^{48}$

This unit is well known for its engagement in the Yugoslav wars, their notoriety brought about in no small measure by the video, and the trials where members were convicted for crimes in Trnovo and Podujevo. Arguably, its notoriety has not eclipsed that of Arkan's men, also captured in action, this time by a photographer, Ron Haviv, earlier in the war. ${ }^{49}$ The profile of Scorpions commander Slobodan Medić Boca was, after all, no match for Arkan's, who was a state security hit man, bank-robber with an active Interpol arrest warrant and international notoriety, a paramilitary leader, a political party president and parliament representative, a cultural icon married to a folk star, and a football manager..$^{50}$

Units like the Scorpions were useful to the Serbian regime, as they provided plausible deniability - the opportunity for the regime to distance itself from the unlawful, the illegitimate and the unsavory part of the conquest of territory. ${ }^{51}$ The Scorpions' warpath, as of the other paramilitaries, is best described by the writings and work of Dejan Anastasijević, Filip Švarm and Miloš Vasić, all Serbian journalists. ${ }^{52}$ Scholars, such as Schlichte, Horncastle, Milichevic, Vivod, Colović, and others wrote about the characteristics of those units, and their role in the war.

\section{The Scorpions Video}

Wednesday, June 1, 2005, was supposed to be a regular court day in The Hague, at the ICTY, where Milošević was facing charges for crimes committed in Croatia, Bosnia and Herzegovina, and Kosovo, during the 1990s. That day, witness Obrad Stevanović was on the stand, former assistant to the minister of internal affairs in Serbia, testifying in the former president's defense. Stevanović was claiming that, essentially, Serbia's institutions had nothing whatsoever to do with whatever happened in Srebrenica. ${ }^{53}$ During the cross-examination, prosecutor Geoffrey Nice played the video of the murders in Trnovo, in order to counter the witnesses' claim. Milošević, and his courtappointed counsel, Steven Kay, both objected, questioning authenticity, connections to Srebrenica, and accusing the prosecution of purposefully being manipulative, constructing relationships between the murders and the Serbian state. In the months that followed, the video proved to be authentic, showing a Serbian unit shooting unarmed men. The video was ultimately not admitted into evidence in the Milošević trial, but in the trials that followed it became immensely important. ${ }^{54}$

\footnotetext{
${ }^{47}$ Fond za humanitarno pravo, Škorpioni od zločina do pravde, 108.

${ }^{48}$ Stojanović, Škorpioni Spomenar, min 37; Fond za humanitarno pravo, Škorpioni od zločina.

${ }^{49}$ Vladimir Petrović, "Power(lessness) of Atrocity Images: Bijeljina Photos between Perpetration and Prosecution of War Crimes in the Former Yugoslavia," International Journal of Transitional Justice, 9 (2015), accessed July 20, 2017, doi:10.1093/ijtj/ijv010. See also: Photographer Ron Haviv talking about the images for the United States Holocaust Memorial Museum, August 7, 2013, accessed July 21, 2017, https://www.youtube.com/watch?v=Lsg AHcQPUA.

${ }^{50}$ Christopher S. Stewart, Hunting the Tiger: The Fast Life and Violent Death of the Balkans' Most Dangerous Man (New York: St. Martin's Press, 2007).

${ }^{51}$ Jan Willem Honig and Norbert Both, Srebrenica: Record of a War Crime (New York: Penguin Books, 1997), 75; James Ron, "Territoriality and Plausible Deniability: Serbian Paramilitaries in the Bosnian War," in Death Squads in Global Perspective, ed. Bruce B. Campbell and Arthur D. Brenner (London: Palgrave, 2000).

${ }^{52}$ Anastasijević, Kratka istorija paravojnih jedinica; Vasić and Švarm, Paramilitary Formations in Serbia.

${ }^{53}$ The arguments regarding Srebrenica presented by the defense teams in various ICTY trials, but also within the nationalist circles of Serbian society is that: a) what happened in Srebrenica was not a systematic effort to exterminate a group (and they adamantly reject the legal qualification of 'genocide' and claim it is a manipulation to smear the Serbs as a nation, b) deaths that occurred among the Bosniaks were a result of the spontaneous revenge of local Serbs for crimes they themselves have suffered during the war, by the Bosnian Muslims, and c) they passionately reject the broadly accepted number of those killed (around eight thousand individuals) and claim many of the victims died while fighting (making them 'legal' casualties, as according to international humanitarian law, it is only illegal to kill civilians, prisoners of wars and others hors de combat). Finally, and most importantly, what happened in Srebrenica was a Bosnian Serb affair and Serbia had nothing to do with it.

${ }^{54}$ Petrović, A Crack in the Wall of Denial, 97
} 
The video was filmed by a member of the unit, Slobodan Stojković Bugar. It was not intended for publication and sharing widely, and thus, depicts members of the Scorpions unit, presumably, doing what they do, in its truest form. If it can be at all said that they are performing, then they are performing for those immediately around them, and possibly others who approve of the act. The video also shows that, at that time, even though this was two years after the establishment of the ICTY, these men had no fear about recording a murder, nor particular worries that it may lead to them being prosecuted for what they have done. In 1995, the ICTY was hardly a considerable threat, barely a case or two in the making, not yet powerful enough in the eyes of those men who probably thought they were engaging in legitimate state business. This is, furthermore, an amateur video-it only films, somewhat with a shaky hand, what was - there does not seem to be much of an agenda behind it. The video includes Scorpions banter, jokes, and what seems to be unrehearsed behavior.

The nineteen minutes that show the execution are actually part of a two-hour collage, filmed largely by Scorpions member Duško Kosanović Sova, who on that fateful day was not present. Sova had had, as he described, a fight with the commander the day before, and left. ${ }^{55}$ The camera stayed, and Slobodan Stojković Bugar took over the filming duties. As part of the collage, the viewer can see scenes from a blessing ceremony, where an orthodox priest named Gavrilo sends the men off to go to the war theater, asking the almighty to give strength to the most faithful Serbian army to fight and win against the enemy of the Serbian people. ${ }^{56}$

The answer to the question of why the execution was filmed is still largely speculative. ${ }^{57}$ Journalist, researchers and analysts looked into statements made by members of the unit, the commander Boca, the videographer, trying to understand the reasoning behind the decision to film. During the trial Boca responded to the judges' question about why he ordered it to be filmed with a counter question, asking, essentially, if the judge thought he was an idiot. Boca was, clearly, becoming well aware of the judicial value of this footage. ${ }^{58}$

Pero Petrašević, one of the members of the unit who was charged but, unlike others, pleaded guilty, told the court that Boca seemed visibly agitated as he issued the order to his closest subordinates, all members of his personal security detail, which made Petrašević think that Boca himself received the order to execute these men. Petrašević immediately asked his commander why the execution was being filmed, to which Boca told him to relax, suggesting the footage would later be deleted. Petrašević speculated that the video was created in order to prove to those that issued the order to Boca, that the execution indeed took place. If that is true, and executions were being filmed, why has no other footage emerged by now? However, once back in Đeletovci, Petrašević realized that some of the men who were not deployed around Trnovo saw the footage and then it occurred to him that recording it was the stupidest thing to do. ${ }^{59}$ The videographer of most of the other footage, Sova, spoke about filming as one would about documenting an interesting excursion, to make something of a memento to their time in the field. Was the execution video a memento, or not, it is hard to know.

According to the testimony of Slobodan Stojković Bugar, he was filming simply because Sova

${ }^{55}$ Stojanović, Škorpioni Spomenar, min 32-34; Fond za humanitarno pravo, Škorpioni od zločina. In his testimony, Slobodan Stojković Bugar claims that Sova got ill and that was the reason he returned home, 348, http://www.hlc-rdc.org/wpcontent/uploads/2012/06/Skorpioni.pdf.

${ }^{56}$ The segment depicting the ceremony with the orthodox priest can be viewed here, accessed on July 30, 2017, http:// srebrenica.sense-agency.com/en/.

${ }^{57}$ Multiple theories were presented through the years about why the camera was there, and none was so far proven. One was centered on the assumption that the State Security demanded to record the shootings, as a proof that they were done. That theory would mean that there may be other images and footage still to be uncovered. Another theory is that they filmed themselves on their own accord, but that this was not done in order to have a memento, but as a way to pressure the State Security with potentially uncovering the story of the murders, and speaking publicly about who gave them the order to execute the men. A similar theory is that the footage was made in order to keep the executioners in line, as leverage against them ever going to the authorities to rat out their comrades.

${ }^{58}$ Fond za humanitarno pravo, Škorpioni od zločina, 59.

${ }^{59}$ Ibid., 92 
was not there to do it. ${ }^{60}$ While testifying in the trial in Belgrade, Bugar stated that, overall, the unit was being filmed so that the commander would have the recording as a souvenir. Sova was apparently brought into the unit with the particular task of filming. ${ }^{61}$ Slobodan Stojković Bugar recalled, during the Scorpions Belgrade trial, that on the morning of the event, he was told by the commander to go and film "it," and said that he did not ask what precisely "it" was. This is what Bugar was told, according to his testimony, by Slobodan Medić Boca, as he was instructing the others to go complete the assignment. ${ }^{62}$ The commander, Boca, gave a completely different account. He was claiming in court that he had nothing to do with the crime, that he did not order it and that most certainly, he had nothing to do with it being taped. According to Boca, he had learned of the event much later. ${ }^{63}$ If he had known that a crime had taken place and that someone filmed it, Boca stated, "Ja bih ga ko zeca ubio" or "I would have killed him like a rabbit." 64

The commander's position during the entire trial was that he did not order any execution, and that his men acted independently. That is a claim all but one of his former subordinates rejected..$^{65}$ According to Pero Petrašević, Boca issued an order-to kill the "soldiers" in the truck. According to Boca, they were captured soldiers. ${ }^{66}$ The accused Petrašević, like others such as the cameraman Slobodan Stojković Bugar, testified that Boca was an authority in the unit and that his men respected him. ${ }^{67}$ Without the commander's approval, they could not move from their positions. ${ }^{68}$ To the judges at the opening of the trial, Petrašević said that in front of god, he is guilty, but what the judges have to determine is if he is guilty for executing an order in war. ${ }^{69}$

The video circulated in the town of Sid, somewhat underground, among members of the unit, their supporters, and others with some connections to the right people. In 2004, the tape was given by one of the Scorpions to the NGO Humanitarian Law Center (HLC), a well-known Serbian human rights organization specializing in documenting crimes and wartime abuses. Nataša Kandić, the head of the Center, approached the Serbian War Crimes Prosecutor Vladimir Vukčević and demanded action. Action did, after significant pressure, follow. ${ }^{70}$ During that period, another tape with the same content, originating in Bosnia, found its way to the ICTY Prosecutor's Office in The Hague. As this case shows, secrets like this are hard to keep when there is a tape recording somewhere.

\section{The Execution}

From the crime after the fall of Srebrenica, and the set of events that create that cluster of organized, systematic executions, this particular fragment of video emerges to depict the atrocity. The relevant bit of the video, for the purposes of this article, begins in the back of a truck. Men are seen on the floor, and it is difficult to see where one person ends, and another begins. We see the legs of a Scorpions member later identified later as Pero Petrašević, sitting in the back of the truck, wearing army boots. All of a sudden, one boot kicks a body on the floor: "Šta se treseš, pička ti materina?" or "Why are you shaking, you motherfucker?"71

\footnotetext{
${ }^{60}$ Prosecutor v. Zdravko Tolimir, November 25, 2010, IT-05-88/2, 8118 - 8119, accessed July 28, 2017, http://www.icty.org/x/ cases/tolimir/trans/en/101125ED.htm.

${ }^{61}$ Fond za humanitarno pravo, Škorpioni od zločina, 346

62 Ibid., 327.

${ }^{63}$ Ibid., 55.

${ }^{64}$ Fond za humanitarno pravo, Škorpioni od zločina, 55

${ }^{65}$ Ibid., 82. Branislav Medić supported Boca's version of events.

${ }^{66}$ Ibid.

${ }^{67}$ Ibid., 94, 355.

${ }^{68}$ Centar za mir Osijek. Zločin u Godinjskim Barama 1995. godine, opt. Milorad Momić; Testimony of witness Damir Hovan, March 26, 2015, accessed July 26, 2017, http://www.centar-za-mir.hr/sudenja-za-ratne-zlocine-2015/zlocin-ugodinjskoj-bari-1995-godine-opt-milorad-momic/.

${ }^{69}$ Fond za humanitarno pravo, Škorpioni od zločina, 593.

${ }^{70}$ Nataša Kandić, Introduction, Škorpioni od zločina do pravde (Belgrade: Humanitarian Law Center, 2008), 7-8.

${ }^{71}$ Sense News Agency, "Prisoner Execution Footage," Srebrenica: Genocide in Eight Acts, accessed September 11, 2018, http://srebrenica.sense-agency.com/en/. All translations are by the author, unless otherwise specified.
} 
Members of the unit around the truck make comments about the detainees smelling badly. The Scorpions use particular words one would use with a toddler, and a particularly high-pitched voice, when suggesting that the men defecated, and urinated on themselves. They do this to mock them, make them feel emasculated. It is worth remembering, the killings took place in July, and the detainees have probably been captured several days before. It was a hot summer, and temperatures rose upwards of 30 degrees Celsius. They probably had not eaten or drank in days, not to mention showered, or changed their clothes.

After the initial few minutes where the camera is pointing to the group of people on the floor, in the back of the truck, we see them emerge from the truck, while the Scorpions yell at them "yalla, yalla,"72 Arabic for "come on, come on", and asking rhetorical questions such as if they were rushing when they were murdering Serbs. The unit members yell, go on, on your knees - "klanjaj, pička vam materina" - "pray, motherfuckers," ${ }^{73}$ a reference to the Muslim prayer, performed on the knees. Both the term "yalla" and the reference to Muslim prayer seem to be used to re-confirm the identity of the detainees as non-Christians, Islamists, Turks, and undeserving of humane, dignified treatment. ${ }^{74}$

"Kad si Srbe ubijao, nisi čeko', pička ti materina."

"When you murdered Serbs, you didn't wait around, did you, you motherfucker."75

The unit members taunt the prisoners, saying they will kill two of them, and let four go-the four best ones. One person lying in the ditch says, calmly, "ubijte me, al' dajte mi vode" - "kill me, but give me water." The unit members respond with: "silence, head down!"76 There is no evidence of the Scorpions ever trying to check if the men they had in their custody were suspected of any crimes, or if they were soldiers. For them, it seemed enough that they were Muslims, and that was the reason these men were killed. That is what Pero Petrašević said to the mothers and family members of the victims in court, after pleading guilty: "Ubili smo ih zato što su bili Muslimani" or "We killed them because they were Muslims."77

The six detainees jumping out of the truck were rushed to a nearby ditch, next to the road, where they were told to lie down. The first to jump out was seventeen-year old Safet Fejzić. The detainees were dirty, their clothes stained and wrinkled, at least one of them had what looks like blood and swelling on his face, and shoeless... Their hands were tied behind their backs. They looked at the floor at all times. They spoke little, and mostly in response to questions. The younger among them seemed particularly petrified, their shoulders down, as if trying to become so small that they would disappear from that moment, from that place. Once on their feet again, the members of the Scorpions unit kept yelling at the prisoners to move quicker.

Once the men are out of the truck, it was easier to see them, and they were identified as: Safet Fejzić (17 at time of death), Azmir Alispahić (17), Sidik Salkić (36), Smail Ibrahimović (35), Dino Salihović (16), Juso Delić (25). That identification was confirmed as bodies were found close to the execution site around the time the video became public, and DNA analysis established that it was indeed them. In sharp contrast to the mood and appearance of the captured men and boys, are the

72 "Yalla, yalla" is also a common term in that region, used when moving cattle in the field (e.g. cows or sheep) and it may indicate that, apart from being a reference to the Muslim origin of the captives, the Scorpion members yelling it also considered the detained men and boys to be cattle-like.

${ }^{73}$ Sense News Agency, Prisoner Execution Footage.

${ }^{74}$ In this context "Turk" is a reference to the Ottoman empire and its rule in the Balkans when some of the local populations converted to Islam. The fact that they left Christianity for a perceived better social position is considered by many contemporary nationalists as something Bosnian Muslims should be ashamed of, as an act of opportunism and weakness by their ancestors. For more on the term "Turk", see Michael Sells, The Bridge Betrayed: Religion and Genocide in Bosnia (Berkeley: University of California Press, 1998).

${ }^{75}$ Sense News Agency, Prisoner Execution Footage.

${ }^{76} \mathrm{Ibid}$.

${ }_{77}$ Bojan Tončić, “Ratni zločinac Slobodan Medić poginuo na slobodi," E-Novine, January 3, 2014, accessed July 20, 2017, http://www.e-novine.com/srbija/96448-Ratni-zloinac-Slobodan-Medi-poginuo-slobodi.html. 


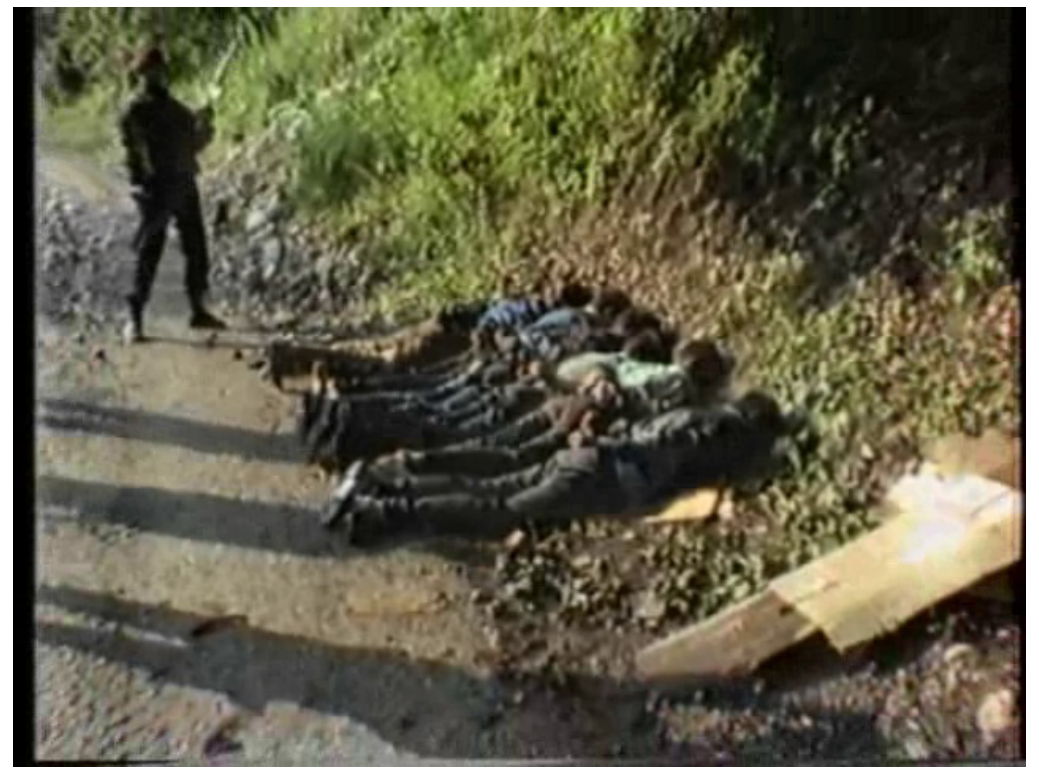

Figure 1. Scorpions member standing next to the victims.

members of the unit surrounding them. They seem well fed, and well dressed, in dark uniforms, some wearing red berets, carrying rifles. Some of them are bulky and muscular. There are one or two seemingly older men, while the rest look to be in their twenties. They comment, with laughter and slight irritation, when the filmmaker yells out, somewhat bemused, that the battery ran out, and that he would have to rush back to the camp for a full one. It is then clear that what is about to happen could not happen without a camera present.

We hear another Scorpions member, Aleksandar Medić, turn towards the 17-year old Azmir on the ground and say: "Jesi li prcao? ... E pa ni nećeš" or "Have you ever fucked? ... Well, you won't."'78

If it is not clear up to that point to the viewer, what is going on, at this precise moment, it becomes clear. There is no doubt in the minds of those present about what is about to happen. Interestingly, the same man, Aleksandar, who spoke those horrible words to the petrified young man-did not shoot when the time for it came. Aleksandar Medić kept his barrel raised in the air, and he did not fire just minutes after this short conversation took place. For it, he suffered ridicule and humiliation from his comrades. ${ }^{79}$

In the video, men walk around carrying weapons, while captives lie in the dirt next to a road. After that, they are escorted to a nearby meadow, lined up in tall grass, close to some holiday cottages long unused due to war, and shot. Each victim looks on, as others standing in front are shot in the back by outbursts of fire. One by one, four fall down. Two are left to pick up the four bodies, their hands now untied, and take them inside an abandoned house. ${ }^{80}$

As the two carry the bodies, they are advised not to look at the faces, presumably not to feel sick, as they drag the lifeless bodies away. The last two men are then shot. Just before that, one of the two asked to drink some water he saw in a bowl, or ashtray, on the windowsill of the abandoned house. He was allowed to do so.$^{81}$ One of the unit members then used his last remaining bullets on them, while another walks in and says he'll 'stamp' them, meaning - put another bullet in their heads, just to make sure they are dead. As they inspect the bodies, a unit member says " $a u$

\footnotetext{
${ }^{78}$ Fond za humanitarno pravo, Škorpioni od zločina, 365.

${ }^{79}$ Ibid., 100.

${ }^{80}$ Centar za mir Osijek. Zločin u Godinjskim Barama 1995. Testimony of witness Amor Mašović.

${ }^{81}$ Fond za humanitarno pravo, Škorpioni od zlocina, 389.
} 


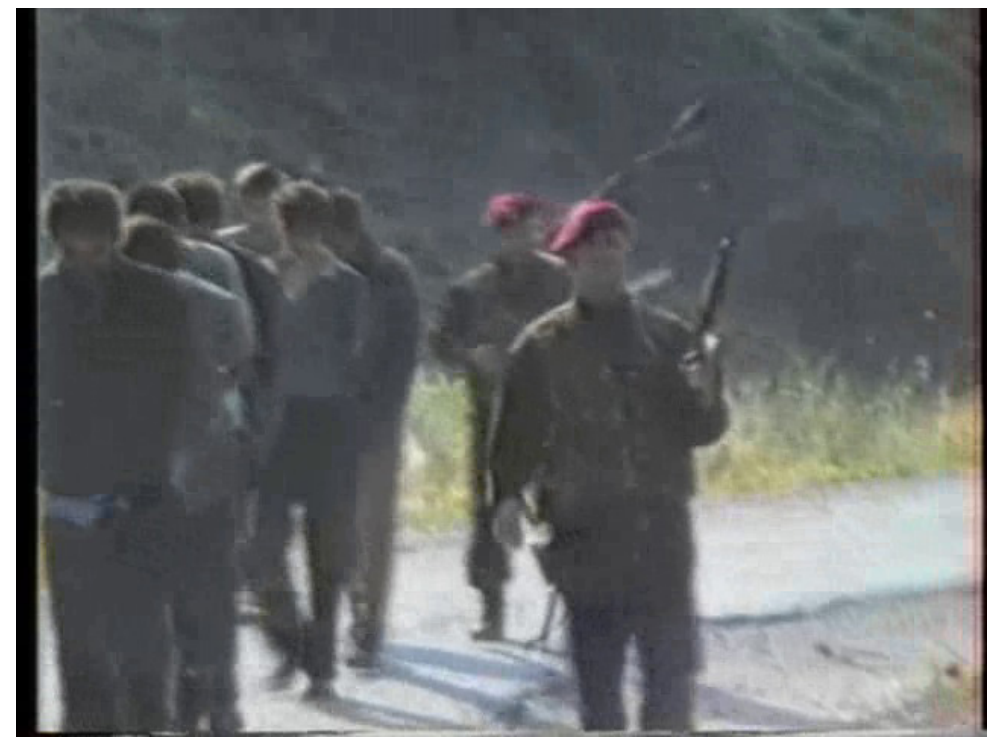

Figure 2. Victims being escorted to the execution site.

pičku materinu, ovaj jos diše" or "For fucks' sake, this one is still breathing." 82 After the members of the unit make sure the last victim is dead, they leave the house. Bodies are then left, piled up in the corner. When they were found, as Amor Mašović had testified, their bones were burned, and that made the process of DNA extraction and identification harder. ${ }^{83}$

The victims never pleaded for their lives, even when it became painfully clear that they were about to end. They never fought, or tried to escape. They asked for water, and asserted their innocence when taunted and accused of abusing Serbs. None of it mattered. The perpetrators did not face any punishment at the time, and members of the same unit deployed again, in four years time, to Kosovo. In this respect, it can be argued that a lack of punishment for the execution in Trnovo made the crime in Podujevo in 1999, more likely.

\section{The Consequences}

The executed men were found in shallow graves close to the execution site, identified, and returned to families for proper burial. However, at the time when the video was released, members of the families were shocked to see it replayed on TV, over and over again. Until then some were still probably holding on to some hope that their loved ones may be alive, somewhere, maybe in a detention camp. As the video was released, that hope was shattered. Azmir Alispahić's mother turned on the TV to watch the evening news that day, while in a refugee camp near Tuzla, Bosnia, and then she saw him. He was the second in line to get shot. She recalls the men in the video pushing him, and just seconds later they shot him. She said to those interviewing her: "no one can understand how I feel."

The son of Sidik Salkić spoke publicly, many years later, about seeing his father being murdered, on TV, while living as a refugee in Australia. Sidik worked in the hospital in Srebrenica, and his son remembered his father wearing the same blue shirt on the video, that he wore when they said goodbye, as Srebrenica was falling. ${ }^{84} \mathrm{He}$ was wearing that same shirt that his son had

\footnotetext{
82 Sense News Agency, Prisoner Execution Footage.

${ }^{83}$ Centar za mir Osijek. Zločin u Godinjskim Barama 1995. Testimony of witness Amor Mašović.

${ }^{84}$ Families separated as the enclave was falling and many women, children and elderly people went to the UN compound in Potočari (just a few kilometers from Srebrenica), and men went towards the forests, and tried to make their way to the territory held by the Bosnian government. The men wanted to reach Tuzla and did not want to be captured by the Bosnian Serb forces. On their way, many were attacked, captured and taken to execution sites in the days and weeks that followed.
} 
seen him wear countless times before. ${ }^{85}$ Hana Fejzić recognized her seventeen-year-old son Safet Fejzić in the footage and testified about it in court. She said that he was wearing the tracksuit she bought for him. ${ }^{86}$

The experiences of family members of these victims raise an important ethical question: do families need to be identified, contacted, and consulted, before any footage of this sort is broadcast in court? The answer is yes, whenever possible, absolutely. There is no need for families to be further traumatized by insensitive judicial institutions. In cases where there are conflicts between the needs and desires of families of victims with respect to evidence like this, and the requirements put forward by the judicial process, relatives need to be consulted, informed and warned, and treated with utmost care and respect, as to avoid inflicting additional harm. A separate issue concerns the ethical use of images like this in the media (in this case, in particular TV and print). Following the video being shown in the ICTY courtroom, it was broadcast at least two thousand times, and TV stations in Serbia and Bosnia showed it more than 500 times. ${ }^{87}$ That in itself made it impossible for most family members to escape seeing it, repeatedly, for weeks. The pain and anguish that that caused the family members of the victims is difficult to imagine.

\section{Judicial and Social Aftermath}

Srebrenica-Related Trials

Broadly speaking, in war crimes trials, there are two kinds of evidence presented by the prosecution: crime-base and linkage. ${ }^{88}$ Furthermore, there is lead evidence, and corroborative evidence. ${ }^{89}$ For judges, evidence must work well together to convincingly prove allegations. For anyone working on prosecuting those cases, crime-based evidence tends to be easier to obtain, verify, and present in court because it speaks about a crime that was committed, and those immediately at the crime scene. It may contain testimonies of eyewitnesses, survivors, and alike. Linkage, on the other hand, focuses on those higher up the chain of command, most often far away from the crime scene, who claim they had no intention to commit any crime, had no information their troops were engaging in crimes, and whoever may have transgressed was doing so on their own accord, and not based on any orders. Linkage is necessary to convict anyone higher up - it needs to prove that commanders and politicians ordered, or were aware of what was happening, and intended the outcome, or at least tolerated it, and that troops were acting under a functioning authority. In this case, the Scorpions video was proof that a crime had been committed by a unit, which was, we now know, affiliated with the Serbian Ministry of Internal Affairs. ${ }^{90}$

The emergence of the video had a great impact on trials going on in The Hague and in Serbia. In the days after its release, members of the Scorpions were arrested, and in the following two years faced trial at the newly established War Crimes Chamber at the Belgrade District Court. ${ }^{91}$ This video made it impossible to paint Srebrenica as a purely Bosnian Serb affair, completely detached from Belgrade. The video has been shown in multiple ICTY trials after 2005, and is currently among the most important visual evidence in the retrial of Jovica Stanišić and Franko Simatović. Key post-

\footnotetext{
85 Insajder, Paravojna Jedinica Škorpioni, film (2006; Belgrade: TV B92), min 18, 28, https://www.youtube.com/ watch? $\mathrm{v}=\mathrm{hQNePutCvPk}$.

${ }^{86}$ Blic, "Priznao zločin posle izjava majki ubijenih," January 26, 2006, accessed July 22, 2017, http://www.blic.rs/vesti/ hronika/priznao-zlocin-posle-izjava-majki-ubijenih/jef0v8v.

${ }^{87}$ Fond za humanitarno pravo, Škorpioni od zločina, 9.

${ }^{88}$ Maria Nystedt, Christian Axboe Nielsen, and Jann K. Kleffner, A Handbook on Assisting International Criminal Investigations (Stockholm: Swedish National Defense College, 2011), 43, accessed July 26, 2017, https://fba.se/contentas sets/6f4962727ea34af5940fa8c448f3d30f/handbook-on-assisting-international-criminal-investigations.pdf.

${ }^{89}$ Witness, Using Video for Documentation and Evidence, July 21, 2014, accessed July 22, 2017, https://www.newtactics.org/ conversation/using-video-documentation-and-evidence.

${ }^{90}$ The trial record in the Stanišić and Simatović ICTY case (and now MICT), testimonies of former members such as Goran Stoparić, as well as statements members gave after the war in documentaries point to this conclusion. See, for example, accessed December 12, 2017, http://www.balkaninsight.com/en/article/scorpions-ex-fighter-says-belgradecontrolled-paramilitaries-12-01-2017.

${ }^{91}$ OSCE. War crimes proceedings in Serbia (2003-2014), 2015, accessed July 23, 2017, http://www.osce.org/ serbia/194461?download=true.
} 
2005 ICTY Srebrenica trials include Zdravko Tolimir, Popović et al., and Radovan Karadžić and Ratko Mladić (both currently awaiting appeal judgments). In those trials, a number of Bosnian Serb officers were convicted of genocide and other crimes, for executions following the fall of Srebrenica ${ }^{92}$ In November 2017, Mladić heard the first instance judgment, sentencing him to life imprisonment. ${ }^{93}$

For the purposes of this article, the focus is on those who actually committed the massacre, and not those who ordered it, or have done nothing to prevent it, or punish the lower-level perpetrators in the aftermath. That is because the video and testimony of unit members in subsequent trials speak volumes about these men, the unit, and the crime they committed. After the footage was released, some of them were charged, along with their commander (who was not at the execution site and is not captured on video). The accused were commander Slobodan Medić Boca (39 at time of charging), Pero Petrašević (36), Aleksandar Medić Zara (38), Aleksandar Vukov Vuk (33) and Branislav Medić Zekan (36). The trial had flaws critics were eager to point out, such as the fact that genocide was not charged and that the court was not convinced that the victims had anything to do with Srebrenica, but overall, it was fair to the accused, and a step in the right direction for Serbia and its judiciary. ${ }^{94}$

The Scorpions were charged with committing crimes against civilians, a war crime. ${ }^{95}$ Slobodan Medić and Branislav Medić were convicted to the maximum available sentence, twenty years in prison, while Aleksandar Medić got five. Aleksandar Vukov was acquitted. Pero Petrašević, after pleading guilty, was sentenced to thirteen years in prison. ${ }^{96}$ The Supreme Court largely upheld convictions, but reduced Branislav Medić's sentence to 15 years, and returned the case of Aleksandar Medić for retrial. ${ }^{97}$

Other trials were conducted in the following years. Slobodan Davidović Boda, and Milorad Momić, both members of the unit present at the execution, were tried in Croatia. Both were convicted..$^{98}$ On December $31^{\text {st }} 2013$, as he was on his way to the New Years' celebration with his wife and seventeen-year old son, Slobodan Medić Boca, the commander of the Scorpions, was killed by a drunk driver. The Toyota Medić's family was in, was crushed. His wife and son were killed too. ${ }^{99}$ Boca was out of prison for the holidays, something that was later heavily criticized by human rights advocates and the families of the victims. ${ }^{100}$

\section{Impact of the Video on Serbian Society}

In the days after it was released, reactions poured in, and politicians and public figures gave statements with varying degrees of genuine shock, and demands for justice. ${ }^{101}$ The video was

${ }^{92}$ The treatment of the massacre in Trnovo in a number of ICTY cases against higher-level accused requires a lengthy discussion that falls beyond the scope of this paper.

${ }_{93}$ Prosecutor v. Ratko Mladic, Trial Judgment, November 22, 2017, IT-09-92, accessed on December 3, 2017, http://www.icty. org/x/cases/mladic/tjug/en/171122-1 of5 1.pdf.

94 Tanja Tagirov, “Istina, ali samo pravosudna," Vreme, April 12, 2007, accessed July 20, 2017, http://vreme.com/cms/view. php?id=494573.

${ }^{95}$ Fond za humanitarno pravo, Škorpioni od zločina, 13.

${ }^{96}$ Ibid., 599.

${ }^{97}$ Blic, “Vrhovni sud uvažio žalbe Škorpiona," September 11, 2008, accessed July 21, 2017, http://www.blic.rs/vesti/ hronika/vrhovni-sud-uvazio-zalbe-skorpiona/f1ssmrv.

${ }_{98}$ Slobodan Davidović Boda was convicted to 15 years in prison in December 2005, for war crimes against the civilian population in Bosnia, and against prisoners of war in Croatia. Davidović was arrested in the aftermath of the release of the video. More here, accessed December 10, 2017, http://www.centar-za-mir.hr/en/ps/zlocin-u-trnovu-i-boboti/. More on the Momić case, accessed December 10, 2017, http://www.centar-za-mir.hr/sudenja-za-ratne-zlocine-2015/ zlocin-u-godinjskoj-bari-1995-godine-opt-milorad-momic/.

${ }_{99}^{9}$ Blic, "Komandant Škorpiona sa porodicom krenuo na doček, ubio ih pijani vozač," January 1, 2014, accessed July 21, 2017, http://www.blic.rs/vesti/hronika/komandant-skorpiona-sa-porodicom-krenuo-na-docek-ubio-ih-pijani-vozac/ mb0x0jv.

${ }^{100}$ Bojan Tončić, “Ratni zločinac Slobodan Medić poginuo na slobodi," E-Novine, January 3, 2014, accessed July 20, 2017, http://www.e-novine.com/srbija/96448-Ratni-zloinac-Slobodan-Medi-poginuo-slobodi.html.

${ }^{101}$ Petrović, A Crack in the Wall of Denial, 104. 
viewed by many, and quickly, as the Milošević trial was followed by the media with greater attention than any other trial. ${ }^{102}$ Nothing like this video had ever been shown in mainstream media in Serbia. There were also outright denials following the video being released, coming mostly from the nationalist right. ${ }^{103}$ Serbian politicians, to this day, in accepting facts from Srebrenica and referring publicly to it, tend to, with the very next breath, refer to crimes suffered by Serbs. While it is absolutely true that Serb civilians suffered as victims of crimes, no genocide was established to have been committed against them in the 1990s wars. ${ }^{104}$ However, in an attempt to equalize, balance and dismiss any notion that troops fighting for the Serbian political project perpetrated a crime that is in any way different from other crimes in the 1990s, politicians emphasize crimes against Serbs. It is rare to hear a singular acceptance of what happened after Srebrenica fell, without the mandatory "but" coming right after it.

As for the social aftermath of the release of the video, now, more than twelve years on, it is clear that its impact was limited, but it did fundamentally change how Srebrenica is perceived. Serbian journalist and ICTY prosecution witness Dejan Anastasijević concluded that there would always be a number of people who will deny that any crime was committed. There are those that will, because of political interests or direct involvement, refuse to acknowledge the crimes no matter the evidence. However, in the aftermath of the video, the average Serbian citizen will, Anastasijevic argues, probably think twice before saying that no crimes were committed in Srebrenica, or that it was not really a big deal. ${ }^{105}$

Importantly, Serbian civil society, and organizations like the Helsinki Committee, and the Humanitarian Law Center, continue to work tirelessly on disseminating important facts about Srebrenica in Serbia. In 2017, the HLC released a dossier that concluded, based on credible evidence, that Serbian institutions were responsible for turning men who fled from Bosnian Serb troops after the fall of Srebrenica and reached Serbia, right over to those that would later kill them. ${ }^{106}$

\section{Conclusion}

The Scorpions video is among some of the most recognizable imagery of the Yugoslav wars, alongside Ron Haviv's series of images of Arkan's unit in Bijeljina in April 1992, and the footage British journalists filmed in the summer of the same year in Omarska and Trnopolje, two large camps close to Prijedor in western Bosnia. That material has been made part of the trial record in numerous cases, in multiple jurisdictions, most notably in The Hague. For Srebrenica, we also have the footage Serbian journalist Zoran Petrović Piroćanac filmed while being embedded with Bosnian Serb forces after the fall of Srebrenica. Out of that footage, a few seconds depicting dead bodies in front of the Kravica warehouse, is most relevant. Those images helped prosecutors prove the organized and systematic expulsions, detentions and executions. In the case of Srebrenica, they helped prove genocide.

However, there is only one video of executions that has emerged - the video discussed in this article. The killing of the six men and boys sometime after July 16, 1995, in a hamlet near Trnovo, almost two hundred kilometers from Srebrenica, was, unlike others, recorded. In that respect, it is different than other mass executions at sites like the Kravica warehouse, Orahovac, the Petkovci dam, Kozluk, Pilica or Branjevo farm, all locations of mass executions in the aftermath of the fall of Srebrenica. The murder of the six unarmed men took place after the mass executions that followed in the week after July 11, but is part of the efficient system of killing the Bosnian Serb Army, and in particular its security apparatus, aided by the police, committed in various locations around eastern Bosnia.

\footnotetext{
${ }^{102}$ Ivan Zverzhanovski, "Watching War Crimes: The Srebrenica Video and the Serbian Attitudes to the 1995 Srebrenica Massacre," Southeast European and Black Sea Studies, 7, no. 3 (2007), 422.

${ }^{103}$ Gordy, Guilt, Responsibility and Denial, 133.

${ }^{104}$ At the International Court of Justice, at the ICTY, and in national courts - no such finding was made at any of the courts, in relation to individual criminal responsibility or state responsibility.

${ }^{105}$ Block, Execution Video Shocks Serbia.

${ }^{106}$ Humanitarian Law Center, “Deportation of Srebrenica Refugees,” July 13, 2017, accessed July 28, 2017, http://www. hlc-rdc.org/?p=33971\&lang=de.
} 
This video provides, in the words of the perpetrators themselves, a sense of just what sort of humiliation the victims had to go through before they were murdered. It gives insight into how the victims were perceived by the perpetrators: as weak, unmanly, dirty and smelly. The victims were yelled at and insulted. Victims were thirsty, a particular detail that already emerged in previous Srebrenica trials at the ICTY. ${ }^{107}$ As evidence, the video was crucial in proving that Srebrenica was not a completely Bosnian Serb affair, with which Belgrade's institutions had nothing whatsoever to do with. As Dejan Anastasijević argued, the Scorpions were not a Bosnian Serb unit. This video was the key evidence proving participation of units from Serbia proper in the crimes committed after the fall of Srebrenica. ${ }^{108}$

For prosecuting mass atrocity crimes, it is further important to point out that this video has not only been used to prosecute individuals up the chain of command, but has served to pressure Serbian institutions into arresting and prosecuting members of the Scorpions unit that committed the crime. Without the video, these men almost certainly would not have been held accountable. It is unlikely they would have come forward on their own. What the developments surrounding the video prove is that evidence like this can push institutions into action. It can, however briefly, open the space for discussions about what was done in war, and in whose name. ${ }^{109}$ The question remains, how many murderers and war criminals are currently on the streets of the former Yugoslavia, because they were never shortsighted enough to film what they were doing?

The Scorpions told stories of unit honor and sacrifice in court, about how life on the frontline is hard, and how they obeyed orders. As the trial transcripts show, the unit commander denied having anything to do with the crime, and members claimed they were ordered to do it, and put on the spot with little choice. They argued that commander Boca had absolute power and that they would never have done something like that without clear instructions, as he was perceived to be a tough commander, and one that does not tolerate disobedience.

The video and subsequent trial record show that the perpetrators had no doubt about what they were doing, and that there was little insecurity or remorse. Maybe the fact that Aleksandar did not shoot can be interpreted as insecurity, and Petrašević pleading guilty could be understood as a sign of remorse. However, some members seemed to have enjoyed the act of killing. They seemed absolutely untouched by what they had done and their acts appeared to be part of a routinenothing in their behavior suggested that this was in any way a new situation for them. In the years after, unit members did not come forward, tormented by guilt, to confess their crime.

What the video reveals about perpetrators is that they escape simplistic qualifications and labelling as monsters or sadistic psychopaths. ${ }^{110}$ Reading the words of Pero Petrašević in the Scorpions trial in Belgrade, one sees a man who regrets his act, and claims the duty to obey orders was the reason why he did what he did that day. But do orders justify him kicking a man, while he's on the floor, in the back of a truck? He is the one in the video who asked a frightened detainee why the fuck he was shaking. Aleksandar Medić, who teased with vulgar jokes a 17-year old who was lying on the ground, waiting to be shot, did not pull the trigger when the time came to do so. $\mathrm{He}$ was later resented for it by his peers. Not all members of notorious units participate in committing crimes, and some later step forward and speak about the acts of their comrades, sometimes putting their own lives in grave danger, and subjecting themselves to pressure, threats, and rejection by their social circles. For men like Goran Stoparić, a former Scorpions member who came forward and spoke out, it was anything but easy to testify; yet he has done so repeatedly.

The video and subsequent trial in Belgrade emerged as a result of the dedication and persistence of one individual in particular, Nataša Kandić, an iron-willed human rights advocate. As in other cases around the globe, when it comes to facing the past, human rights groups are the ones pressing for it. The role of HLC in this particular case proves the importance of civil society engagement

\footnotetext{
${ }^{107}$ Prosecutor v. Radislav Krstic, testimony of witness O, April 13, 2000, IT-05-88/2. Transcript page 2911, lines 13-14, accessed July 22, 2017, http://www.icty.org/x/cases/krstic/trans/en/000413ed.htm.

${ }^{108}$ Block, Execution Video Shocks Serbia.

109 Petrović, A Crack in the Wall of Denial, 107

${ }^{110}$ An interesting perspective is provided by Saira Mohammed in "Of monsters and men: perpetrator trauma and mass atrocity," Columbia Law Review, 115/5 (2015), 1157-1216.
} 
in the painful process of facing the past in Serbia. ${ }^{111}$ As unsuccessful as this process seems to be at times, the existence of this video did show, quite literally, to people in Serbia, that men in uniforms, speaking Serbian, did kill unarmed victims in the aftermath of Srebrenica. Up until that point, there was still doubt about Srebrenica in much of Serbian society, and the notion that it was all some kind of fabrication to vilify the Serbs still held, especially in nationalist circles. After the Scorpions video came out, that is no longer the case. ${ }^{12}$ As Orentlicher wrote when referring to the trials at the ICTY, what took place was a "shrinking space for denial"113, however briefly. ${ }^{114}$ That is what happened: today, only those at the very margins of the political discourse would claim nothing at all happened in Srebrenica. There is widespread recognition that the massacre took place, albeit often coupled with efforts to minimize the number of victims.

Currently, the Mechanism for International Criminal Tribunals in The Hague, the daughterinstitution of sorts to the ICTY, is conducting the re-trial of Jovica Stanišić and Franko Simatović, the former head of the Serbian State Security, and his trusted associate. They are charged with crimes committed by units such as the Scorpions, as the two accused were, according to the prosecutors, responsible for their establishment, training, financing and deployment. The crimes charged include persecutions on political, racial or religious grounds, a crime against humanity, and murder as a violation of the laws and customs of war, committed in a number of municipalities in Croatia and Bosnia and Herzegovina. ${ }^{115}$ They were previously tried by the ICTY, and acquitted in 2013, in a controversial decision based on a particular understanding, later dismissed by judges as erroneous, of aiding and abetting as a mode of liability. ${ }^{116}$ The Appeals Chamber of the ICTY then returned the case for re-trial. ${ }^{117}$

In sum, what these nineteen minutes of horror have shown us was tragic, and painful, but also something we had to know if we wanted to know about Srebrenica, the crime that was committed, and the men that committed it. Without it, one could still ask: was it really that horrific? After this video we can confidently say, yes it was, it was that horrific, and worse. It is nineteen minutes of what is among the worst things imaginable that a human being can be subjected to, and that must not be forgotten. Thanks to the evidence that was collected and used in court, and this video, it cannot be.

\section{Acknowledgements}

I wish to thank the Archives and Records Section of the Mechanism for International Criminal Tribunals and my colleagues Vladimir Petrović and Jelena Stevančević on the assistance they provided as I worked on this article.

\section{Bibliography}

Anastasijević, Dejan. “Kratka istorija paravojnih jedinica u jugoslavenskim ratovima 1991-1995 Grabljive zveri i otrovne bube." YU Historija, n.d. Accessed July 25, 2017. http://www. yuhistorija.com/serbian/ratovi 9199 txt01c.html. . “Ubod Škorpiona.” Vreme, December 25, 2003. Accessed July 21, 2017. http://www.vreme. com/cms/view.php?id=361981.

\footnotetext{
${ }^{111}$ Olivera Simić and Zala Volčić, eds., Transitional Justice and Civil Society in the Balkans (New York: Springer, 2013).

${ }^{112}$ Beti Bilandzic, "Murder video broadcast stuns disbelieving Serbs," Reuters, June 4, 2005, accessed July 24, 2017, http:// www.theage.com.au/news/World/Murder-video-broadcast-stuns-disbelieving-Serbs/2005/06/03/1117568372197.html.

${ }^{113}$ Diane Orentlicher, Shrinking the Space for Denial: The Impact of the ICTY in Serbia (New York: Open Society Institute, 2008).

${ }^{114}$ Petrović, A Crack in the Wall of Denial, 107.

${ }^{115}$ Prosecutor v. Jovica Stanisic and Franko Simatovic, Third Amended Indictment, July 9, 2008, IT-03-69-PT, accessed on July 20, 2017, http://www.icty.org/x/cases/stanisic simatovic/ind/en/staj-in3rdamd080710.pdf.

${ }^{116}$ Prosecutor v. Jovica Stanisic and Franko Simatovic, Trial Judgment, May 30, 2013, IT-03-69-PT, accessed on July 20, 2017, http://www.icty.org/x/cases/stanisic simatovic/tjug/en/130530 judgement p1.pdf.

${ }_{117}$ Prosecutor v. Jovica Stanisic and Franko Simatovic, Appeals judgment, December 09. 2015, IT-03-69-A, accessed on July 20 , 2017, http://www.icty.org/x/cases/stanisic simatovic/acjug/en/151209-judgement.pdf.
} 
Armatta, Judith. Twilight of Impunity: The War Crimes Trial of Slobodan Milosevic. Durham: Duke University Press, 2010. https://doi.org/10.1215/9780822391791

Associated Press. "Bosnia Agonizes over Release of Massacre Video." June 3, 2005. Accessed July 22, 2017. http://www.nbcnews.com/id/8085091/ns/world news/t/bosnia-agonizes-overrelease-massacre-video/.

Bilandzic, Beti. "Murder Video Broadcast Stuns Disbelieving Serbs." Reuters, June 4, 2005. Accessed July 24, 2017. http://www.theage.com.au/news/World/Murder-video-broadcast-stunsdisbelieving-Serbs/2005/06/03/1117568372197.html.

Blic. "Priznao zločin posle izjava majki ubijenih." January 26, 2006. Accessed July 22, 2017. http://www.blic.rs/vesti/hronika/priznao-zlocin-posle-izjava-majki-ubijenih/jef0v8v. "Vrhovni sud uvažio žalbe Škorpiona." September 11, 2008. Accessed July 21, 2017. http://www.blic.rs/vesti/hronika/vrhovni-sud-uvazio-zalbe-skorpiona/f1ssmrv.

"Komandant Škorpiona sa porodicom krenuo na doček, ubio ih pijani vozač." January 1 , 2014. Accessed July 20, 2017. http://www.blic.rs/vesti/hronika/komandant-skorpiona-saporodicom-krenuo-na-docek-ubio-ih-pijani-vozac/mb0x0jv.

Block, Melissa. “Execution Video Shocks Serbia." NPR, June 3, 2005. Accessed July 18, 2017. http://www.npr.org/templates/story/story.php?storyId=4679742.

Brants, Chrisje and Susanne Karstedt, eds. Transitional Justice and the Public Sphere: Engagement, Legitimacy and Contestation. Oxford: Hart Publishing, 2017.

Biserko, Sonja, ed. Srebrenica: Od poricanja do priznanja. Beograd: Helsinški odbor za ljudska prava u Srbiji, 2005.

Boas, Gideon. The Milosevic Trial: Lessons for the Conduct of Complex International Criminal Proceedings. Cambridge, UK: Cambridge University Press, 2007. https://doi.org/10.1017/ CBO9780511619090

Centar za mir Osijek. Zločin u Godinjskim barama 1995. godine, opt. Milorad Momić, March 26, 2015. Accessed July 26, 2017. http://www.centar-za-mir.hr/sudenja-za-ratne-zlocine-2015/zlocinu-godinjskoj-bari-1995-godine-opt-milorad-momic/.

------. Crimes in Trnovo and Bobota, November 28, 2013. Accessed December 10, 2017. http://www. centar-za-mir.hr/en/ps/zlocin-u-trnovu-i-boboti/.

Didi-Huberman, Georges. Images in Spite of All: Four Photographs from Auschwitz. Translated by Shane B. Lillis. Chicago: University of Chicago Press, 2008.

Drakulić, Slavenka. They Would Never Hurt a Fly: War Criminals on Trial in The Hague. London: Penguin Books, 2004.

Fond za humanitarno pravo. Škorpioni od zločina do pravde, 2008. Accessed July 24, 2017. http://www.hlc-rdc.org/wp-content/uploads/2012/06/Skorpioni.pdf.

Gordy, Eric. Guilt, Responsibility and Denial: The Past at Stake in Post-Milosevic Serbia. Philadelphia: University of Pennsylvania Press, 2013.

Gow, James. The Serbian Project and its Adversaries: A Strategy of War Crimes. London: Hurst \& Company, 2003

Helsinški Odbor. Slučaj Škorpioni, Peščanik, 2008. Accessed July 20, 2017. http://pescanik.net/ slucaj-skorpioni/.

Honig, Jan Willem and Norbert Both. Srebrenica: Record of a War Crime. New York: Penguin Books, 1997.

Humanitarian Law Center. Deportation of Srebrenica Refugees, 2017. Accessed July 28, 2017. http://www.hlc-rdc.org/?p=33971\&lang=de.

Insajder. Paravojna Jedinica Škorpioni. Documentary. Belgrade: TV B92, 2006. Accessed July 25, 2017. https://www.youtube.com/watch?v=hQNePutCvPk.

International Commission on Missing Persons. "Srebrenica: Truth and Justice Are Tools to Tackle Genocide." Press Release, July 11, 2017. Accessed July 25, 2017. https://www.icmp.int/ press-releases/srebrenica-truth-and-justice-are-tools-to-tackle-genocide/.

"Srebrenica Figures as of 02 July 2015." Press Release. Accessed September 11, 2018. https://www.icmp.int/news/infographic-provides-latest-facts-and-figures-on-srebrenicagenocide/. 
Keilbach, Judith. "Photographs, Symbolic Images, and the Holocaust: On the (Im)possibility of Depicting Historical Truth." History and Theory, Theme Issue 47 (2009): 54-76. https://doi. org/10.1111/j.1468-2303.2009.00498.x

Lennon, Helen. "A Witness to Atrocity: Film as Evidence in International War Crimes." In Holocaust and the Moving Image: Representations in Film and Television since 1933, edited by Toby Haggith and Joanna Newman, 65-74. London: Thomson Press, 2005.

Mohammed, Saira. "Of Monsters and Men: Perpetrator Trauma and Mass Atrocity." Columbia Law Review, 115/5 (2015): 1157-1216.

Milutinović, Radoša. "Scorpions' Ex-Fighter Says Belgrade Controlled Paramilitaries." Balkan Insight, December 1, 2017. Accessed December 12, 2017. http://www.balkaninsight.com/ en/article/scorpions-ex-fighter-says-belgrade-controlled-paramilitaries-12-01-2017.

Nystedt, Maria, Christian Axboe Nielsen, and Jann K. Kleffner. A Handbook on Assisting International Criminal Investigations. Stockholm: Swedish National Defense College, 2011.

Orentlicher, Diane. Shrinking the Space for Denial: The Impact of the ICTY in Serbia. New York: Open Society Institute, 2008.

Organization for Security and Co-operation in Europe. War Crimes Proceedings in Serbia (2003-2014), 2015. Accessed July 23, 2017. http://www.osce.org/serbia/194461?download=true.

Petrović, Vladimir. "A Crack in the Wall of Denial: The Scorpions Video in and out of the Courtroom." In Narratives of Justice In and Out of the Courtroom: Former Yugoslavia and Beyond, edited by Dubravka Žarkov and Marlies Glasius, 89-109. New York: Springer, 2013.

. The Emergence of Historical Forensic Expertise: Clio Takes the Stand. New York: Routledge, 2017.

. "Power(lessness) of Atrocity Images: Bijeljina Photos between Perpetration and Prosecution of War Crimes in the Former Yugoslavia." International Journal of Transitional Justice, 9 (2015): 367-385. Accessed July 20, 2017. https://doi.org/10.1093/ijtj/ijv010

Ron, James. "Territoriality and Plausible Deniability: Serbian Paramilitaries in the Bosnian War." In Death Squads in Global Perspective, edited by Bruce B. Campbell and Arthur D. Brenner, 287-312. London: Palgrave, 2000. https://doi.org/10.1057/9780230108141 11

Sells, Michael. The Bridge Betrayed: Religion and Genocide in Bosnia. Berkeley: University of California Press, 1998.

Sense News Agency. "Prisoner Execution Footage." Srebrenica: Genocide in Eight Acts. Accessed September 11, 2018, http://srebrenica.sense-agency.com/en/.

Simić, Olivera and Zala Volčić, eds. Transitional Justice and Civil Society in the Balkans. New York: Springer, 2013. https://doi.org/10.1007/978-1-4614-5422-9

Stewart, Christopher S. Hunting the Tiger: The Fast Life and Violent Death of the Balkans' Most Dangerous Man. New York: St. Martin's Press, 2007.

Stojanović, Lazar. Škorpioni Spomenar. Documentary. Belgrade: Humanitarian Law Center, 2007. Accessed July 25, 2017. https://www.youtube.com/watch?v=nqsDRw04Z6U.

Tagirov, Tanja. "Istina, ali samo pravosudna." Vreme, April 12, 2007. Accessed July 20, 2017. http://vreme.com/cms/view.php?id=494573.

. "Škorpion pred sudom." Vreme, June 16, 2005. Accessed July 20, 2017. http://www.vreme. com/cms/view.php?id=419054.

Tončić, Bojan. "Ratni zločinac Slobodan Medić poginuo na slobodi." E-Novine, January 3, 2014. Accessed July 20, 2017. http://www.e-novine.com/srbija/96448-Ratni-zloinac-SlobodanMedi-poginuo-slobodi.html.

Tromp, Nevenka. Prosecuting Slobodan Milosevic: The Unfinished Trial. New York: Routledge, 2016. https://doi.org/10.4324/9781315659848

United Nations Security Council. Press Release SC/6122/Rev. 1 3591'st Meeting (Night), November 9, 1995.

United States Holocaust Memorial Museum. Interview with Ron Haviv. Washington D.C: USHMM, 2013. Accessed July 25, 2017. https://www.youtube.com/watch?v=Lsg AHcQPUA.

Vasić, Miloš. "Poreklo moći i bogatstva." Vreme, June 16, 2005. Accessed July 30, 2017. http://www. vreme.com/cms/view.php?id=419055. 
Vasić, Miloš and Filip Švarm. "Paramilitary Formations in Serbia: 1990-2000." In In the Triangle of State Power: Army, Police, Paramilitary Units, edited by Stipe Sikavica, 58-77. Belgrade: Helsinki Committee for Human Rights in Serbia, 2001.

Vukušić, Iva. "The Archives of the International Criminal Tribunal for the former Yugoslavia." History: The Journal of the Historical Association, 98, 4, no. 332 (2013): 623-635.

Waters, Timothy, ed., The Milosevic Trial, An Autopsy. Oxford: Oxford University Press, 2014. https://doi.org/10.1093/acprof:oso/9780199795840.001.0001

Wilson, Richard Ashby. Writing History in International Criminal Trials. New York: Cambridge University Press, 2011. https://doi.org/10.1017/CBO9780511973505

Witness. Using Video for Documentation and Evidence, July 21, 2014. Accessed July 22, 2017. https://www.newtactics.org/conversation/using-video-documentation-and-evidence.

Zverzhanovski, Ivan. "Watching War Crimes: The Srebrenica Video and the Serbian Attitudes to the 1995 Srebrenica Massacre." Southeast European and Black Sea Studies, 7, no. 3 (2007): 417430. https://doi.org/10.1080/14683850701566377 